\title{
Analysis of Company Characteristics of Firm Values: Profitability as Intervening Variables
}

\author{
M. Chabachib ${ }^{1}$, Hersugondo Hersugondo ${ }^{1}$, Erna Ardiana ${ }^{1} \&$ Imang Dapit Pamungkas ${ }^{2}$ \\ ${ }^{1}$ Business and Economics Faculty, Universitas Diponegoro, Semarang, Indonesia \\ ${ }^{2}$ Business and Economics Faculty, Universitas Dian Nuswantoro, Semarang, Indonesia \\ Correspondence: Imang Dapit Pamungkas, Business and Economics Faculty, Dian Nuswantoro University, Semarang, \\ Indonesia. Tel: 62-8564-0205-628.
}

Received: July 31, 2019

Accepted: September 13, 2019

Online Published: October 17, 2019

doi:10.5430/ijfr.v11n1p60

URL: https://doi.org/10.5430/ijfr.v11n1p60

\begin{abstract}
This study aims to analyze the factors that influence company value (PBV) in consumer goods companies listed on the Indonesia Stock Exchange in 2014-2018. The independent variables used in the study are capital structure (DER), company size (SIZE), liquidity (CR) with profitability (ROE) as an intervening variable.

The population used in this study is all companies engaged in the consumer goods sector listed on the Indonesia Stock Exchange in 2014-2018. Sampling in this study used purposive sampling which resulted in a sample of 128 consumer goods sector companies. The method used is path analysis which is the development of multiple regression and bivariate analysis.

The results of this study indicate that company size and liquidity have a positive and significant effect on profitability, the capital structure has a negative and not significant effect on profitability. Profitability and company size have a positive and significant effect on firm value. Capital structure and liquidity have a positive and not significant effect on firm value. Then profitability is able to mediate the influence of company size and liquidity on firm value, but profitability is not able to mediate the influence of capital structure on firm value.
\end{abstract}

Keywords: capital structure, company size, liquidity, profitability and company value

\section{Introduction}

Management's performance in running the company can be seen through the company's performance. Company performance is to be as a reflection of the company's ability to achieve its objectives. Financial ratios can be used to know the results of company performance. Alshatti, (2015) suggested that the company has a goal to prosper the owner of the company that is very closely related to the company's ability to make a profit. Therefore, one of the important information when conducting financial statement ratio analysis is the level of profitability, because the company's ability to generate profits is the most effective assessment of company performance. In general, the analysis is done by comparing the achievements of one period with the previous period so that information on trends in a period is obtained. Profitability is an important indicator that reflects the company's ability to fulfill the obligations of funders and components in creating corporate value while ensuring long-term sustainability that determines the company's prospects in the future (Pamungkas, Ghozali, \& Achmad, 2017).

Capital structure is one of the factors that allow to influence the value of the company. Managers in an effort to meet their funding needs must create efficient alternatives. An efficient funding decision can be reached when the company has an optimal capital structure, where the capital structure can minimize the overall cost of capital use (Alshatti, 2015). The company must have conditions that vary in each time, therefore the company's target will change according to its conditions. Management needs to analyze the factors that influence the determination of the targeted capital structure (Pamungkas, Ghozali, Achmad, Khaddafi, \& Hidayah, 2018). The decision on funding with high risk will have an impact on the decline in stock prices but can allow to increase the expected rate of return. Therefore, the optimal capital structure can be achieved by a balance between risk and expected rate of return in an effort to maximize stock prices (Brigham \& Houston, 2012).

Company size is to be as one of the factors considered in determining the value of the company. The size of the company is the scale of determining the size of the company which is seen through the amount of total assets, the 
number of sales, and the stock market value (Nurminda, Isynuwardhana, \& Nurbaiti, 2017). This research company size is measured by the total assets owned, this is because total assets are considered more stable and can better reflect the size of the company. Large companies are believed to have ease in accessing the capital market so that they have the opportunity to get ease of funding, both from internal and external sources. Companies that are classified as large generally have developed, this has been responded positively by investors so that it can increase the value of the company(Utomo, Pamungkas \& Machmuddah, 2018). In addition, large companies also have a relatively small chance of experiencing bankruptcy if exposed to economic problems.

Liquidity illustrates the company's ability to pay short-term financial obligations using current assets owned (Alshatti, 2015) Companies that can fulfill their obligations on time mean the company is in a liquid state because the company has a means of payment or current assets that is greater than its debt. Liquid or not the company will affect the financial position of the company which in turn affects the ability of the company's profitability. Of course investors will be more interested in companies with good financial conditions or in a liquid state. Therefore, by balancing the company's ability to guarantee creditors with their current assets, it can affect the value of the company. A summary of previous studies that showed inconsistencies in the results of the study were addressed by table 1. Research Gap as follows:

Table 1. Research gap

\begin{tabular}{|c|c|c|c|}
\hline Dependent & Independent & Relationship & Researcher \\
\hline & Capital Structure (DER) & (+) Significant & Hamidy et al., (2015) \\
\hline & & & Saraswathi et al., (2016) \\
\hline & & (-) Significant & Sarikadarwati and Afriati (2016) \\
\hline & & & Arif, et al., (2015) \\
\hline & & & Christi et al., (2013) \\
\hline & & Not significant & Mahaputeri and Yadnyana (2014) \\
\hline \multirow{16}{*}{ Profitability (ROE) } & Company Size (Size) & (+) Significant & Ambarwathi et al., (2015) \\
\hline & & & Adebiyi and Sunday (2011) \\
\hline & & & Qiuying Li et al., (2014) \\
\hline & & Not significant & Mahaputeri and Yadnyana (2014) \\
\hline & & & Boadi and Li (2015) \\
\hline & Capital Structure (DER) & (+) Significant & Janthan (2013) \\
\hline & & & Novita and Sofie (2015) \\
\hline & & Not significant & Alagathurai, A. (2013) \\
\hline & & & Malik et al., (2016) \\
\hline & Capital Structure (DER) & (+) Significant & Manopo and Arie (2016) \\
\hline & & & Hamidy et al., (2015) \\
\hline & & & Tahir (2011) \\
\hline & & & Gelatang et al., (2016) \\
\hline & & (-) Significant & Susanto and Juniarti (2013) \\
\hline & & Not significant & Nurminda et al., (2017) \\
\hline & & & Suastini et al., (2016) \\
\hline \multirow[t]{10}{*}{ Firm Value (PBV) } & Company Size (Size) & (+) Significant & Nurhayati (2013) \\
\hline & & & Susanto and Juniarti (2013) \\
\hline & & (-) Significant & Tahir (2011) \\
\hline & & Not significant & Manopo and Arie (2016) \\
\hline & & & Nurminda et al., (2017) \\
\hline & Liquidity & (+) Significant & Novita and Sofie (2015 \\
\hline & & Not significant & Nurhayati (2013) \\
\hline & Profitability (ROE) & (+) Significant & Nurminda et al., (2017) \\
\hline & & (-) Significant & Tahir (2011) \\
\hline & & Not significant & Manopo dan Arie (2016) \\
\hline
\end{tabular}

Source: Various journals that have been published 
Based on Table 1, it can be seen that there are still conflicting results of previous studies with one another, so the research gap is found. There is a Research Gap relationship between variables that is reflected in factual data (average of DER, Ln of Total Assets, CR, ROA and PBV). So it is concluded that there is a gap phenomenon in the 2012-2016 research year. Besides that it is also based on table 1 it can be seen that there are still conflicts of previous research results with one another, so that a research gap is found. While the difference in this study with previous research is the profitability variable (Retun on Equity) used as an intervening variable.So, the researcher wants to do further research by using profitability as an intervening variable. The objectives of this study are as follows: To analyze the effect of capital structure, firm size, liquidity on profitability, To analyze the effect of capital structure, firm size, liquidity on firm value. To analyze the effect of profitability on firm value, to analyze the effect of profitability in mediating the capital structure of firm value, to analyze the effect of profitability in mediating firm size against firm value in the company, to analyze the effect of profitability in mediating liquidity against firm value.

\section{Literature Review and Hyphothesis Development}

\subsection{Signaling Theory}

According to (Brigham \& Houston, 2012) signal is an action from company management to investors by providing instructions or signs regarding management's assessment of the company's prospects. The investor's signal is interpreted as a signal related to the risk and the company's return and the company's prospects in the future. Therefore this information is very important for business people, especially investors, because the information provided by company management is management's performance in an effort to meet the wishes of shareholders. By giving information to the market, it is expected that outside parties can distinguish companies from good conditions and bad conditions. Brigham \& Houston, (2012) assume that every businessman, both investor and manager, has the same information about the prospects of a company, commonly called symmetrical information. But in reality managers actually have more information than investors, which is called asymmetric information. Therefore this signaling is intended to reduce asymmetric information between the management of the company and external parties. The information provided presents an overview or record of the state of the company in the past, present and future that can be analyzed from the company's financial statements. So that information is expected to be relevant, accurate and complete so that investors can use it as a consideration in investment decisions that have an influence on the survival of the company.

\subsection{Capital Structure Negatively Influences Profitability}

Debt to Equity Ratio is a ratio that shows the total debt that the company has on its own capital (Alshatti, 2015). The greater the value of this ratio then indicates the use of large debt as well. When the debt held by a company is high, it will have an impact on the net income earned. This is caused by high debt that will be followed by a high debt burden (interest) so that it can reduce the company's net income. The decrease in net income obtained will result in a decrease in the company's Return on Equity. This is in line with the research conducted by Adebiy; \& Sunday, (2011) which state that capital structure (DER) has a significant negative effect on profitability (ROE). )

H1: Capital structure negatively influences profitability

\subsection{Effect of Company Size on Profitability}

Company size is a scale in determining the size of a company which is reflected in the total assets owned. According (Alagathurai, 2013) explain that critical theory focuses on controlling the owner of the company on resources owned such as technology, assets and intellectual property as a factor in determining the size of the company. Based on the critical resources theory (Alagathurai, 2013) states that the larger the scale of a company, the profitability produced is also higher, but at a certain point the size of the company can also reduce the profitability of the company. Companies with large total assets are considered to have good performance stability so they are believed to be able to generate higher profits because large companies have greater resources in operational activities. The amount of resources owned is used for investment activities in both current assets, fixed assets and to fulfill product demand. So this can expand the company's market share. With the increase in sales, it will cover the costs incurred for the production process. Therefore large companies have an influence on increasing company profitability (Anandasayanan, 2017). The above description is in accordance with the results of research conducted by Adebiy \& Sunday, (2011); which states that firm size has a significant positive effect on profitability.

H2: Firm size has a positive effect on profitability

\subsection{Effect of Liquidity on Profitability}

Liquidity reflects the company's ability to fulfill its short-term financial obligations with its current assets. While 
profitability leads to the company's ability to generate profits. The size of the company's liquidity level will affect the profitability obtained. Within certain limits, the high value of liquidity will have a positive or negative impact on profitability, which can increase or decrease the profitability of the company. However, there is no specific standard for determining a good level of liquidity, while based on the precautionary principle the level of liquidity with a value of around 200\% is considered good for the company's profits (Alshatti, 2015). Company liquidity is reflected in current assets owned, which are assets that can easily be converted into cash. The high level of liquidity indicates that current assets are greater than the company's current debt. This can reduce the high debt and interest expense that must be paid so as to increase the profitability of the company (Novita and Sofie, 2015). Besides that, the amount of current assets available can encourage the high profits obtained by the company. Companies with high levels of liquidity will be spared the risk of the possibility of failure to meet their short-term obligations (Malik et al., 2016). So as to better guarantee the security of the company in increasing profitability. This description is in line with the results of research conducted by Janthan (2013), Novita and Sofie (2015) which states that liquidity has a positive and significant effect on profitability.

H3: Liquidity has a positive effect on profitability

\subsection{Effect of Profitability on Company Values}

Profitability reflects the company's ability to generate corporate profits. Whereas company value reflects the level of success of the company which is shown through shareholder prosperity and the company's stock price. The high profit generated by the company will increase investor confidence in the company which has an impact on increasing stock prices. Based on signal theory, the high profits obtained indicate good corporate prospects in the future, this is interpreted as a signal that is responded positively by investors so that the value of the company increases. Whereas Saraswathi, et al (2016) stated that the high level of corporate profits gave a positive signal to investors on increasing trust, making it easier for management to attract capital in the form of shares which had an impact on the increase in the company's stock price. The description is in accordance with the research conducted by Nurminda et al., (2017); Pamungkas, Ghozali, \& Achmad, (2018) which states that profitability has a positive and significant effect on firm value.

\section{H4: Profitability has a positive effect on firm value}

\subsection{Effect of Capital Structure on Company Values}

The company in running its business requires capital, both from internal (share capital, retained earnings and reserves) and from external sources such as debt. In its funding decisions, companies must really consider efficient alternatives to achieve the company's financial balance to prevent bankruptcy. Capital structure is a balance of the amount of debt with company equity. The high value of Debt to Equity Ratio means the high level of corporate debt so that the interest expense borne also increases. In accordance with signaling theory, the high value of DER is interpreted by investors as a signal that the size of the company's fixed expenses and the high financial risk that must be borne by the company. While investors tend to dislike companies with a high level of risk, so this causes stock prices to decline (Brigham \& Houston, 2012). The description is in accordance with the research conducted by Adebiy \& Sunday, (2011); Boadi \& Li, (2015); Chisti, Ali, \& Sangmi, (2013) which state that the capital structure has a significant negative effect on firm value.

H5: Capital structure has a negative effect on firm value

\subsection{Effect of Company Size on Company Values}

The size of the company can be reflected through the amount of total assets owned by the company. Large-sized companies are defined as having good capacity in running a business. Therefore investors will be more interested in investing in the company. Based on signaling theory, the size of the company is interpreted as a positive signal received by investors that the company has good prospects.states that the amount of assets owned by the company provides management with ease in controlling the company so that it can increase the value of the company. Besides that the shares of large companies are widespread in the capital market, so that they have the ease of obtaining funds because they are trusted by investors to be able to provide high returns (Nurhayati, 2013). Therefore large companies are more in demand by investors, which leads to rising stock prices and high corporate value (Hidayah, 2014). The description is in line with the research conducted by Nurhayati, (2013); Obradovich \& Gill, (2013) which states that firm size has a positive and significant effect on firm value.

H6: Company size has a positive effect on firm value 


\subsection{Effect of Liquidity on Company Values}

Liquidity shows the company's ability to fulfill its short-term financial obligations. Liquidity is proxied by the current ratio, where if the company's current ratio value is high it means that the company's ability to meet short-term financial obligations with current assets is high. In accordance with signaling theory, the company's ability will be responded positively by the market. Companies that have a high level of liquidity will gain investor confidence because it shows that the company has good stability and performance (Nurhayati, 2013). Besides that the high liquidity indicates that the smaller the risk that will be borne on the possibility of failure of the company to pay its short-term obligations, this also has an impact on the small risk borne by the investor. Therefore, the increase in trust in a company will encourage investors to invest their funds so that many requests for company shares will increase the price of their shares.

H7: Liquidity has a positive effect on firm value

\subsection{Effect of Capital Structure on Company Values With Profitability as Intervening Variables}

Capital structure that is proxied by DER (Debt to Equity Ratio) shows the level of debt usage to the total assets of the company. The decision to use debt to the company must use the right proportion, because this policy will affect the company's earnings. The high DER owned by the company reflects that in running its business, the company relies on debt as a source of funding for its operations. Companies that have high debt value will also bear high interest costs. Therefore the use of debt that is too large can reduce the net income obtained by the company due to the amount of repayment that is greater than the amount of debt taken. Based on signaling theory, when profitability decreases, the company's stock price also decreases as a result of signals received by investors that the company does not promise good prospects in the future, thus affecting the value of the company.

H8: Profitability can mediate the effect of capital structure on firm value

\subsection{Effect of Company Size on Firm Value With Profitability as an Intervening Variable}

The size of the company can be seen through the amount of assets the company has. The larger the size of the company, the greater the total assets held so that the resources are large. Large companies show that they have achieved security and success in carrying out their business. This is because the abundance of resources owned is used for investment activities optimally, so that it can meet product demand and expand market share. Therefore it results in increased profits obtained by the company. Besides that large-sized companies can easily access the capital market so that they help companies in their efforts to meet their capital needs (Kusuma, 2005). Investors will be interested in investing in large companies because of the possibility of high returns from profits obtained by the company, which will increase the company's stock price. Rising company stock prices will increase the value of the company (Hidayah, 2014).

H9: Profitability can mediate the influence of firm size on firm value

\subsection{Effect of Liquidity on Company Values With Profitability as an Intervening Variable}

Company liquidity shows the company's ability to fulfill its financial obligations that are due. Liquidity that is predicted by the current ratio provides information about the amount of current assets compared to the company's short-term liabilities. The higher the value of the company's current ratio, the higher the company's ability to fulfill its obligations. The high liquidity of the company means that the company is in a safe condition and far from the risk of bankruptcy due to the inability of the company to pay its smooth debt. This helps smooth the company's operations to generate profits, so that the company's profits increase (Barua, (2013); Tahir \& Razali, (2011); Wu, Marshall, Chipulu, $\mathrm{Li}, \&$ Ojiako, 2014). The high profitability of the company is interpreted as a positive signal by investors, resulting in increased demand for the company's shares. High demand for shares has an impact on rising stock prices and increasing corporate value.

H10: Profitability can mediate the effect of liquidity on firm value

\section{Methods}

The data collection method used in this study is the documentation method by recording and copying data obtained from the Bloomberg website and the annual financial statements of consumer goods companies in the 2014-2018 period which are contained in the Indonesia Stock Exchange. The type of data used in this study is secondary data, while the secondary data itself is data obtained indirectly or through intermediaries. The research data is sourced from Bloomberg and the company's annual financial reports published by the Indonesia Stock Exchange from the site www.idx.co.id. Operational Definition Variables in this study are shown in Table 2. 
Table 2. Variable operational definitions

\begin{tabular}{lllll}
\hline Variabel & Proxy & Information & Scale & Formula \\
\hline Firm Value & (PBV) & $\begin{array}{l}\text { Ratio for analyzing company shares by comparing } \\
\text { the price of shares with book value per share of the } \\
\text { company }\end{array}$ & Ratio & $\begin{array}{l}\text { Share price / } \\
\text { book value per sheet Stock }\end{array}$ \\
\hline Profitability & (ROE) & $\begin{array}{l}\text { ROE is a ratio of profitability that is used to Know } \\
\text { the Company's Ability to Produce Profits By } \\
\text { comparing profit after tax from own capital } \\
\text { owned. }\end{array}$ & Ratio & post-tax profit / \\
& (DER) & $\begin{array}{l}\text { DER is a ratio to determine the company's ability } \\
\text { to fulfill its total debt with its own capital }\end{array}$ & Ratio & Total Amoun of debt/ \\
Structure & (Size) & $\begin{array}{l}\text { The size of the company as a benchmark for the } \\
\text { size of a company that can be seen through the } \\
\text { amount of total assets owned by the company }\end{array}$ & Ratio & Log (Size) \\
\hline Size Company & & $\begin{array}{l}\text { CR is a ratio that compares current assets with } \\
\text { current liabilities owned by the company }\end{array}$ & Ratio & Assets/ Current liabilities \\
\hline Liquidity & (CR) & & \\
\hline
\end{tabular}

Source: (Brigham \& Houston, 2012), (Nurminda et al., 2017).

\subsection{Population and Samples}

Population is a set of objects that are used as objects in a study. The population used in this study is all companies in the consumer good sector listed on the Indonesia Stock Exchange (IDX) in the 2014-2018 period with a total of 137 companies in that period. The selection of samples in this study was carried out by purposive sampling method, namely sampling carried out in accordance with predetermined criteria. Based on the above criteria, the number of samples used in this study is explained in Table 3.

Table 3. Number of study samples

\begin{tabular}{lc}
\hline Criteria & Total Sample \\
\hline Consecutive consumer goods companies are listed on the Stock Exchange in 2014-2018 & 210 \\
\hline Consumer goods companies that have not experienced suspension during the 2014-2018 period & 186 \\
\hline Consumer goods companies that publish their financial statements and data are available & 128 \\
\hline Number of samples & 128 \\
\hline
\end{tabular}

Based on the table above, it can be seen the number of samples in this study were 128 companies.

\subsection{Analysis Methods}

The data analysis technique used in this study is Path Analysis. Path analysis is used to determine the direct effect and indirect influence of the independent variables on the dependent variable. (Latan \& Ghozali, 2012) states that path analysis is an extension of multiple linear regression and bivariate which can test causally between variables based on linear equations and allow for testing with intervening variables.

\section{Result and Discussion}

Descriptive statistical analysis aims to describe all variables in this study. Descriptive statistical test results of mean values, minimum values, maximum values and standard deviation values of each research variable, namely capital structure (DER), company size (SIZE), liquidity (CR), profitability (ROE) and firm value (PBV). This study uses the intervening variable profitability that is proxied by ROE. Path analysis is used to analyze the construct power between variables for the direct, indirect and total influence of the independent variables on the dependent variable. The path analysis in this study is presented as follows: 


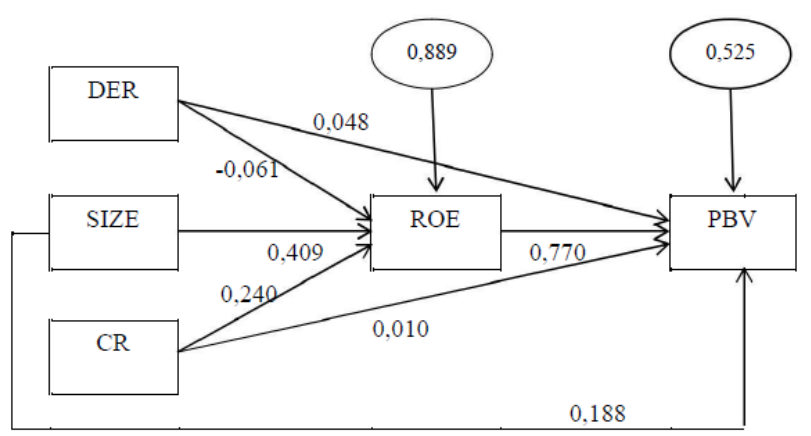

Figure 1. Analysis of the path of effect of DER, SIZE, CR on PBV with ROE as intervening variables

From Figure 1 it can be seen the results of multiple linear regression analysis of the two equations so that the value of the Beta Standardized Coefficients is obtained and the error value obtained from the calculation of each equation. Testing to prove the significance of the influence of mediation can be done by sobel test (Latan \& Ghozali, 2012). Sobel test aims to determine the strength of the indirect influence between the independent variable $(\mathrm{X})$ on the dependent variable $(\mathrm{Y})$ through the intervening variable $(\mathrm{M})$. The following is a summary of the sobel test results of this study with the independent variable DER, SIZE, CR on the dependent variable PBV through the intervening ROE variable.

Table 4. Sobel test results

\begin{tabular}{llll}
\hline Variables & $\mathbf{t}$ count & $\mathbf{t}$ table & Information \\
\hline DER & $-2,494$ & 1,65 & $\mathrm{t}$ count $<\mathrm{t}$ table \\
\hline SIZE & 11,629 & 1,65 & $\mathrm{t}$ count $<\mathrm{t}$ table \\
\hline CR & 11,5 & 1,65 & $\mathrm{t}$ count $<\mathrm{t}$ table \\
\hline
\end{tabular}

Table 5. Summary of hypothesis tests

\begin{tabular}{lll}
\hline Hypothesis & Result & Conclusion \\
\hline DER has a negative (-) effect on ROE & Negative and insignificant & H1 Rejected \\
\hline SIZE has a positive (+) effect on ROE & Positive and significant & H2 Accepted \\
\hline CR has a positive (+) effect on ROE & Positive and significant & H3 Accepted \\
\hline ROE has a positive (+) effect on PBV & Positive and significant & H4 Accepted \\
\hline DER has a negative effect (-) on PBV & Positive and significant & H5 Rejected \\
\hline SIZE has a positive (+) effect on PBV & Positive and significant & H6 Accepted \\
\hline CR has a positive (+) effect on PBV & Positive and not significant & H7 Rejected \\
\hline ROE mediates the effect of DER on PBV & Not mediating & H8 Rejected \\
\hline ROE mediates the effect of SIZE on PBV & Mediate & H9 Accepted \\
\hline ROE mediates the effect of CR on PBV & Mediate & H10 Accepted \\
\hline
\end{tabular}

\subsection{Effect of Capital Structure (DER) on Profitability (ROE)}

Based on the testing of the first hypothesis the results show that the capital structure has a negative and not significant effect on profitability. Thus hypothesis 1 is rejected. This statement is evident from the regression coefficient value owned by DER towards ROE with a negative direction of -0.012 and a significance value of 0.608 where the value is greater than the significance level of 0.05 . So that the capital structure (DER) has a negative and not significant effect on profitability (ROE). This means that the high DER value will reduce the profitability of consumer goods companies, but the effect is not significant. DER has a non-significant negative effect. Every company that takes a debt must be prepared to return the debt along with its interest. This means that the amount of liabilities that must be returned is greater than the amount of debt taken. When a company has high debt, the higher the amount of liabilities to pay. The 
use of debt will increase the company's burden, but this has no significant effect on the decline in profits obtained by consumer goods companies in 2012-2016. Even though consumer goods companies have a high liability due to the use of debt, the company can manage debt usage properly so that it does not have a significant impact on reducing the profitability of the company.

\subsection{Effect of Company Size (SIZE) on Profitability (ROE)}

Based on the results of testing the second hypothesis states that SIZE has a significant positive effect on ROE, then hypothesis 2 is accepted. These results are evident from the SIZE regression coefficient with a positive direction of 0.021 and a significance value of 0,000 where the value is much smaller than the 0.05 significance level. The size of the company (SIZE) has a significant positive effect on profitability (ROE) meaning that every increase that occurs in the size of the company or total assets owned, the profitability of the company will also increase. The size of the company is reflected in the large total assets of the company, where the high number of assets owned gives evidence of the company's reliability. Besides that, companies with large assets have good working stability and are able to generate higher profits because of the many resources they have. This is in line with the critical resouces theory which states that the larger the scale of a company, the higher the profitability that will be produced (Alagathurai, 2013). The results of this study are in line with the results of research from Adebiy \& Sunday, (2011) which states that firm size has a positive and significant effect on profitability (ROE).

\subsection{Effect of Liquidity (CR) on Profitability (ROE)}

Based on the testing of the third hypothesis results that CR has a positive and significant effect on ROE. This is evident from the $\mathrm{CR}$ regression coefficient with a positive direction of 0.013 with a significance value of 0.045 where the value is below 0.05 . Liquidity (CR) has a significant positive effect on profitability (ROE), meaning that every higher level of company liquidity, the higher the profitability of the company. Liquidity (CR) has a significant positive effect on profitability (ROE). The level of liquidity of the company reflects the amount of current assets and current debt which also describes the ability of the company to meet its short-term obligations with its current assets. The higher current ratio indicates the higher the company's ability to fulfill its obligations because available current assets are greater than the company's current debt. The high level of liquidity of the company results in a small risk of bankruptcy being borne, so this helps smooth the company in carrying out activities as an effort to create profits. Thus the high level of liquidity held has an impact on increasing profitability. Alshatti, (2015) state that based on the precautionary principle, the value of liquidity that is considered good is around $200 \%$.

\subsection{Effect of Profitability (ROE) on Company Values (PBV)}

Based on the fourth hypothesis testing states that ROE has a positive and significant effect on PBV, then hypothesis 6 is accepted. This is evident from the ROE regression coefficient with a positive direction of 0.928 with a significance value of 0,000 where the value is much smaller than 0.05 . Then it was concluded that profitability (ROE) has a significant positive effect on firm value (PBV). This statement means that every increase that occurs in profitability, the value of the company will also increase, and vice versa. ROE has a positive and significant effect on firm value. ROE as a reflection of the company's ability to generate profits from its own capital. ROE indicates how much profit investors will receive, so investors will be more interested in companies that have high profit rates. This result is in line with the theory of signaling where when ROE increases it is considered a signal for investors that the prospect is good in the future. The increasing potential profit of the company will increase investor confidence in the demand for shares resulting in high stock prices which also impact on increasing the value of the company. The results of this study are in line with the results of research by (Nurminda et al., 2017) which states that profitability (Return On Equity) has a positive and significant effect on company value (Price to Book Value).

\subsection{Effect of Capital Structure (DER) on Company Values (PBV)}

Based on the testing of the fifth hypothesis the results show that DER has a positive and not significant effect on PBV, then hypothesis 5 is rejected. This is evident from the DER regression coefficient with a positive direction of 0.221 with a significance value of 0.497 where the value is greater than 0.05. Capital structure (DER) does not have a significant positive effect on firm value (PBV), meaning that any increase or decrease in DER does not affect the value of the company. The high value of DER means that the high debt used by companies to fund their assets. Based on signaling theory, companies that use a lot of debt as a source of funding are interpreted as goodnews by investors because they indicate the good performance of the company so that the company is brave to take large debts. But on the other hand, the high debt will also result in the higher interest expense that must be borne by the company, so investors also interpret it as a signal that the amount of risk inherent in the company. The signal inequality interpreted by investors is the cause of the absence of the influence of the high and low value of the debt to equity ratio to the value of 
the company. The results of this study are in accordance with the research conducted by Nurminda et al., (2017) which states that DER has a positive and insignificant effect on firm value.

\subsection{Effects of Company Size (SIZE) on Company Values (PBV)}

Based on the sixth hypothesis testing obtained the results that the size of the company (SIZE) has a significant positive effect on firm value (PBV), then hypothesis 6 is accepted. This is derived from the SIZE regression coefficient with a positive direction of 0.220 with a significance value of 0.001 where the value is much smaller than 0.05 . SIZE has a significant positive effect on PBV which means that the increasing total assets or size of the company, the value of the company will increase. The size of the company has a positive and significant effect on PBV. Large companies are measured by the amount of assets they have in which large companies have good operational performance and are considered well-established. This is in accordance with the signaling theory where the increasing reliability of the company is interpreted as a positive signal for investors that the company has good prospects in the future. Increasing investor trust and interest will result in rising stock prices which ultimately increases the value of the company. The results of this study are consistent with the results of (Nurhayati, 2013) which state that firm size has a significant positive effect on firm value.

\subsection{Effect of Liquidity (CR) on Company Value (PBV)}

Based on the seventh hypothesis testing shows that CR does not significantly influence positively on PBV, then hypothesis 7 is rejected. This is evident from the CR regression coefficient with a positive direction of 0.013 with a significance value of 0.890 where the value is more than 0.05 . Liquidity (CR) has a positive and insignificant effect on firm value (PBV) which means that any increase or decrease in the value of the Current Ratio has no effect on Price to Book Value. Companies with high Current Ratio indicate the higher the company's ability to fulfill its financial obligations with its current assets. Referring to the signaling theory, it will be considered a positive signal by investors, so that it can increase the value of the company. However, the results of this study state that liquidity (CR) has no significant effect on PBV. This is because investors do not only look at the level of liquidity in assessing the company. Besides that, if the high level of liquidity is above the optimal limit, it will reduce the value of the company because it indicates that there are idle company assets that are not used efficiently by company management. CR does not have a significant effect on firm value, meaning that investors in investing do not consider the current ratio factor of a company. This liquidity ratio only provides information on the ability of a company to meet current liabilities with its assets. While not closing the possibility of the size of the company's liquidity ratio dominated by the high value of the company's inventories and receivables. Therefore investors are not interested in seeing the liquidity factor as a consideration for investing. The results of this study are in accordance with (Nurhayati, 2013) who suggested that the Current Ratio has a positive and insignificant effect on firm value.

\subsection{Effect of Capital Structure (DER) on Firm Value (PBV) With Profitability (ROE) as Intervening Variables}

In the eighth hypothesis test results that profitability (ROE) as an intervening variable is not able to mediate the effect of capital structure (DER) on firm value (PBV), then hypothesis 8 is rejected. This is obtained from the results of the sobel test where $t$ count is smaller than $t$ table $(-0.5<1.65)$. The amount of the debt to equity ratio reflects that the high debt used by companies to fund their assets. While the high debt will increase the burden and risk borne by the company. But the magnitude of the company's burden due to the use of debt does not have a significant effect on the decline in profitability. Therefore, profitability is not able to mediate the effect of capital structure on firm value. Besides that, it can also be concluded that the high and low debt does not have an impact on the value of the company through the profits obtained. The results of this study are in accordance with the results of the study by Pratama and Wiksuana (2016) which states that profitability is not able to mediate the effect of capital structure on firm value.

\subsection{Effect of Company Size (SIZE) on Firm Value (PBV) With Profitability (ROE) as Intervening Variables}

Based on the ninth test shows that profitability (ROE) as an intervening variable successfully mediates the effect of firm size on firm value (PBV), then hypothesis 9 is accepted. This is evident from the value of the sobel test where the value of $t$ count is greater than the value of $t$ table (>1.65). The results of this study conclude that Consumer Goods companies on the Indonesia Stock Exchange can increase the value of their companies by increasing the size of the company or total assets owned. By increasing assets, the company can also increase the profit generated because of the abundance of resources it has. High profitability will increase investor confidence so that it can increase the company's stock price. Thus indirectly the size of the company can increase the value of the company through profitability.

\subsection{Effect of Liquidity (CR) on Firm Value (PBV) With Profitability (ROE) as Intervening Variables}

Based on the testing of the tenth hypothesis the results that $\mathrm{ROE}$ as an intervening variable is able to mediate the effect of CR on PBV, then hypothesis 10 is accepted. This is evident from the results of the sobel test which states that the 
value of $\mathrm{t}$ count is greater than $\mathrm{t}$ table ( $2>1.65$ ). The results of this study state that the company Consumer Goods on the IDX can increase its corporate value (PBV) by increasing liquidity (CR) owned. High liquidity will increase the profitability of consumer goods companies because the available current assets are greater than the company's current liabilities. The high profitability will be attractive to investors, thereby increasing the company's stock price. Thus the amount of liquidity will indirectly increase the value of the company through the profitability of the company. Based on some of these analyzes, for investors who want to invest in a company, investors should not only analysis the company but also pay attention to economic conditions (Utomo \& Pamungkas, 2018).

\section{Conclussion}

This study shows that the capital structure (DER) has a negative and not significant effect on profitability (ROE). Company size has a positive and significant effect on profitability (ROE). Liquidity (CR) has a positive and significant effect on profitability (ROE). Profitability (ROE) has a positive and significant effect on firm value (PBV). Capital structure (DER) has a positive and not significant effect on firm value (PBV). Firm size has a positive and significant effect on firm value of firm value (PBV). Partially the liquidity variable that is proxied by the Current Ratio has a insignificant positive effect on firm value which is proxied by Price to Book Value. Thus liquidity (CR) has a positive and not significant effect on firm value (PBV). Profitability is not able to mediate the influence of capital structure on firm value. Profitability is able to mediate the influence of company size on firm value. Partially Return On Equity is able to mediate the influence between the Current Ratio to Price to Book Value. Thus it can be concluded that profitability is able to mediate the influence of liquidity on firm value. The independent variable in the first equation includes DER, SIZE, CR as a whole has an effect on ROE. Then concluded that the independent variables in the first equation simultaneously affect the intervening variable profitability (ROE).

\subsection{Limitation}

In this study there are some limitations, among others, the adjusted $\mathrm{R}$ square value on the dependent variable profitability (ROE) of 0.188. This value means that the independent variable (Debt to Equity Ratio, Company Size, Current Ratio) is only able to affect the dependent variable Return On Equity by $18.8 \%$, where the remaining $81.2 \%$ is influenced by other variables outside the model used in the study.

The second limitation of the research lies in the adjusted $\mathrm{R}$ square value of the dependent variable firm value (PBV) that is equal to 0.714. This value means that the independent variable (Debt to Equity Ratio, Company Size, Current Ratio and Return On Equity) is only able to affect the dependent variable Price to Book Value of $71.4 \%$, where the remaining $28.6 \%$ is influenced by other variables outside research model. Thus for further research is expected to consider other factors beyond the model used in this study.

\subsection{Recommendation}

\subsubsection{For Investors}

Prospective investors can use the results of this study as a reference for consideration before deciding to invest in order to get results in line with expectations. Referring to the results of the study, it was found that the factors that most influence the firm's value are Return On Equity and company size. So that it is expected for investors and potential investors from now on not only using the profitability of the company in considering investment decisions.

\subsubsection{For Further Researchers}

For further researchers, it is expected to continue to search for other variables outside the model that can be added as research variables, for example by adding variables in terms of the ratio of company activities such as total asset turnover. It aims to obtain research results that are more accurate and are common to all companies. The time period of the study also influences the results of the study, especially if the research time tends to be short so it is feared to cause biased results. Thus, it is expected for further research to use a relatively long period of time in order to obtain accurate results.

\section{References}

Adebiy, A., \& Sunday, K. (2011). Ownership Structure and Dirm Performance: Evidance From Nigerian Listed Companies, 8(4), 391-400.

Alagathurai, A. (2013). A nexus between liquidity \& profitability: a study of trading companies in Sri Lanka. Ajanthan, A.(2013). A Nexus Between Liquidity \& Profitability: A Study Of Trading Companies In Sri Lanka. European Journal of Business and Management, 5(7), 221-237.

Alshatti, A. S. (2015). The Effect of the Liquidity Management on Profitability in the Jordanian Commercial Banks, 10(1), 62-72. https://doi.org/10.5539/ijbm.v10n1p62 
Anandasayanan, S. (2017). The effects of liquidity management on firm profitability: Evidence from Sri Lankan listed companies. TRANS Asian Journal of Marketing \& Management Research (TAJMMR), 6(2and3), 32-41.

Barua, P. (2013). The Moderating Role of Perceived Behavioral Control: The Literature Criticism and Methodological Considerations. International Journal of Business and Social Science, 4(10), 57-59.

Boadi, E. K., \& Li, Y. (2015). An Empirical Analysis of Leverage and Financial Performance of Listed Non-Financial Firms in Ghana. International Journal of Economics and Finance, 7(9), 120-130.

Brigham, E. F., \& Houston, J. F. (2012). Fundamentals of Financial Management Eleventh Edition.

Chisti, K. A., Ali, K., \& Sangmi, M.-D. (2013). Impact of capital structure on profitability of listed companies (evidence from India). The USV Annals of Economics and Public Administration, 13(1 (17)), 183-191.

Hidayah, N. (2014). The effect of company characteristics toward firm value in the property and real estate company in Indonesia Stock Exchange. International Journal of Business, Economics and Law, 5(1), 1-8.

Kusuma, H. (2005). Size Perusahaan dan Profitabilitas: Kajian Empiris terhadap Perusahaan Manufaktur yang Terdaftar di Bursa Efek Jakarta. Economic Journal of Emerging Markets, 10(1).

Latan, H., \& Ghozali, I. (2012). Partial Least Squares Konsep, Metode, dan Aplikasi Menggunakan Program WarpPLS 2.0. Semarang: Badan Penerbit Universitas Dipenogoro, 224.

Nurhayati, M. (2013). Profitability, Liquidity, and Company Size Influence On Dividend Policy and Corporate Value of Non Service Sector. Journal of Finance and Business, 5(2), 145-153.

Nurminda, A., Isynuwardhana, D., \& Nurbaiti, A. (2017). Pengaruh Profitabilitas, Leverage, dan Ukuran Perusahaan Terhadap Nilai Perusahaan. E-Proceeding of Management, 4(1).

Obradovich, J., \& Gill, A. (2013). The impact of corporate governance and financial leverage on the value of American firms.

Pamungkas, I. D., Ghozali, I., \& Achmad, T. (2017). The effects of the whistleblowing system on financial statements fraud: Ethical behavior as the mediators. International Journal of Civil Engineering and Technology, $8(10)$.

Pamungkas, I. D., Ghozali, I., \& Achmad, T. (2018). A pilot study of corporate governance and accounting fraud: The fraud diamond model. Journal of Business and Retail Management Research, 12(2).

Pamungkas, I. D., Ghozali, I., Achmad, T., Khaddafi, M., \& Hidayah, R. (2018). Corporate governance mechanisms in preventing accounting fraud: A study of fraud pentagon model. Journal of Applied Economic Sciences, $13(2)$.

Tahir, I. M., \& Razali, A. R. (2011). The Relationship between enterprise risk management (ERM) and firm value: Evidence From Malaysian public listed companies. International Journal of Economics and Management Sciences, 1(2), 32-41.

Utomo, D., Pamungkas, I. D., \& Machmuddah, Z. (2018). The Moderating Effects of Managerial Ownership on Accounting Conservatism and Quality of Earnings. Academy of Accounting and Financial Studies Journal, 22(6), 1-11.

Utomo, S. D., \& Pamungkas, I. D. (2018). Cash Flow Activities and Stock Returns in Manufacturing of Indonesia: A Moderating Role of Earning Management, 22(6), 1-10.

Wu, Y., Marshall, A., Chipulu, M., Li, Q., \& Ojiako, U. (2014). Enterprise risk management and firm value within China's insurance industry. Professional Accountant, 14(1), 1-10. 